RESEARCH ARTICLE

\title{
Improving Rice (Oryza sativa L.) Productivity through Plant Growth Regulators and Nutrients
}

\author{
Kunjammal $\mathbf{P}^{* 1}$ and Sukumar $\mathbf{J}^{2}$ \\ *1 Department of Agronomy, Tamil Nadu Agricultural University, Coimbatore - 641003. \\ ${ }^{2}$ Rathanavel Subaramaniyam - Krishi Vigyan Kendra, Tirunelveli - 627852.
}

Received : $31^{\text {st }}$ January, 2020

Revised : $21^{\text {st }}$ February, 2020

Accepted : $24^{\text {th }}$ February, 2020

\section{ABSTRACT}

A field experiment was conducted at the College of Agricultural Technology, Kullapuram, Theni during 2016-2017 on enhancing rice (Oryza sativa L.) productivity through plant growth regulators and nutrients. The experiment was laid out in Randomized Block Design with eight treatments replicated thrice. The results revealed that foliar spray of Triacontanol $2 \mathrm{ppm}+$ Polyfeed $1 \%+\mathrm{KCl} 1 \%$ given at 35 and 65 DAT along with the application of a recommended dose of fertilizer increased all yield attributes viz., number of productive tillers $\left(540 \mathrm{~m}^{-2}\right)$, panicle length $(22.8 \mathrm{~cm})$ and decreased sterility level (13.4\%). Further, the treatment recorded a higher grain yield of $6.1 \mathrm{t} \mathrm{ha}^{-1}$ and straw yield of $6.77 \mathrm{t} \mathrm{ha}^{-1}$. The result of the study revealed that foliar application of Triacontanol 2 ppm + Polyfeed 1\% $+\mathrm{KCl} 1 \%$ applied at 35 and 65 DAT along with a recommended dose of fertilizer enhanced the grain yield in ADT 47 rice variety during rabi season.

Keywords: Rice, Triacontanol, $\mathrm{KCl}$, Polyfeed.

\section{INTRODUCTION}

Rice (Oryza sativa L.) is a staple food for millions of people in the world, particularly in developing countries. About 90 per cent of rice grown in the world is produced and consumed in Asian countries. India rank first in respect of area (44.50 million ha), second in production (102.75 million tonnes), with the productivity of rice $\left(2.20 \mathrm{t} \mathrm{ha}^{-1}\right)$. Rice productivity level could not be maintained because of significant control exercised by seasons. When compared to rice grown under summer season (4.79 $\left.\mathrm{t} \mathrm{ha}^{-1}\right)$, the yield of rabi season rice is much lower (3.94 t ha-1), and this could be attributed to a lower level of solar radiation and decreased temperature prevailing during rabi season (GOTN, 2015). Under low light conditions, the crop suffered due to higher sterility, which accounted for low yields during the rabi season.Physiological efficiency, including the photosynthetic ability of plants and, offer a significant role in realizing higher crop yields. Though the PGR has great potential, its application and accrual assessments etc., have to be judiciously planned in terms of optimal concentration, stage of application, and seasons. Nutrients also have an important role in plant metabolism, growth, and developmental processes and help in increasing biomass production and yield. In this context, a field experiment was conducted to maximize the production of rabi season rice through foliar nutrition of plant growth regulators, and nutrients to evolve

*Corresponding author's e-mail: kunjammalpandi@gmail.com the best PGR and nutrient foliar spray combination for rabi rice on their growth and productivity.

\section{MATERIAL AND METHODS}

The field experiment was conducted during Rabi 2016 - 17 at the College of Agricultural Technology, Kullapuram, Theni situated in the Southern agroclimatic zone of Tamil Nadu at $10^{\circ} 5^{\prime} \mathrm{N}$ latitude and $77^{\circ} 5^{\prime} \mathrm{E}$ longitude at an altitude of $40 \mathrm{~m}$ above mean sea level. The soil of the experimental field was sandy clay loam in texture with the available nitrogen $234.26 \mathrm{~kg} \mathrm{ha}^{-1}$, phosphorus $16.76 \mathrm{~kg} \mathrm{ha}^{-1}$, potassium $294.24 \mathrm{~kg} \mathrm{ha}^{-1}$ and organic carbon content $0.30 \%$. The experiment was laid out in a randomized block design and replicated thrice. The experiment consisted of eight treatments with different nutrients and growth regulator viz., $\mathrm{T}_{1}$ : Triacontanol $2 \mathrm{ppm}+$ Polyfeed $1 \%+\mathrm{KCl} 1 \%, \mathrm{~T}_{2}$ : Triacontanol + Polyfeed 1\%, $\mathrm{T}_{3}$ : Triacontanol $+\mathrm{KCl}$, $\mathrm{T}_{4}$ : Polyfeed $+\mathrm{KCl}, \mathrm{T}_{5}$ : Triacontanol, $\mathrm{T}_{6}$ : Polyfeed $1 \%, \mathrm{~T}_{7}: \mathrm{KCl} 1 \%$ and $\mathrm{T}_{8}$ : control i.e., no foliar spray. Foliar spray of plant growth regulator and nutrient was done at 35 DAT and 65 DAT as per the treatment schedule. Blanket recommendation of 150:50:50 kg NPK ha ${ }^{-1}$ were applied commonly to all the treatments. The various biometric observations, analytical data of plant sample, and the computed data were subjected to the statistical tool as per the procedure given by Gomez and Gomez (1984). The treatment differences were worked out at a five per cent probability level.

$107|1-3| 40$ 


\section{RESULTS AND DISCUSSION}

\section{Effect of foliar spray on growth characters}

A significant difference in plant height at different growth stages was observed due to the different foliar applications of plant growth regulators and nutrients (Figure 1). At harvest, the plant height (92 $\mathrm{cm}$ ) and DMP (631 kg/ha) were significantly higher with the application of Triacontanol 2 ppm + Polyfeed $1 \%+\mathrm{KCl} \%$, which was followed by Polyfeed $1 \%+$ $\mathrm{KCl} 1 \%$. Improvement in growth parameters due to triacontanol might be ascribed to higher photo synthetic efficiency and a rapid increase in the net assimilation rate.
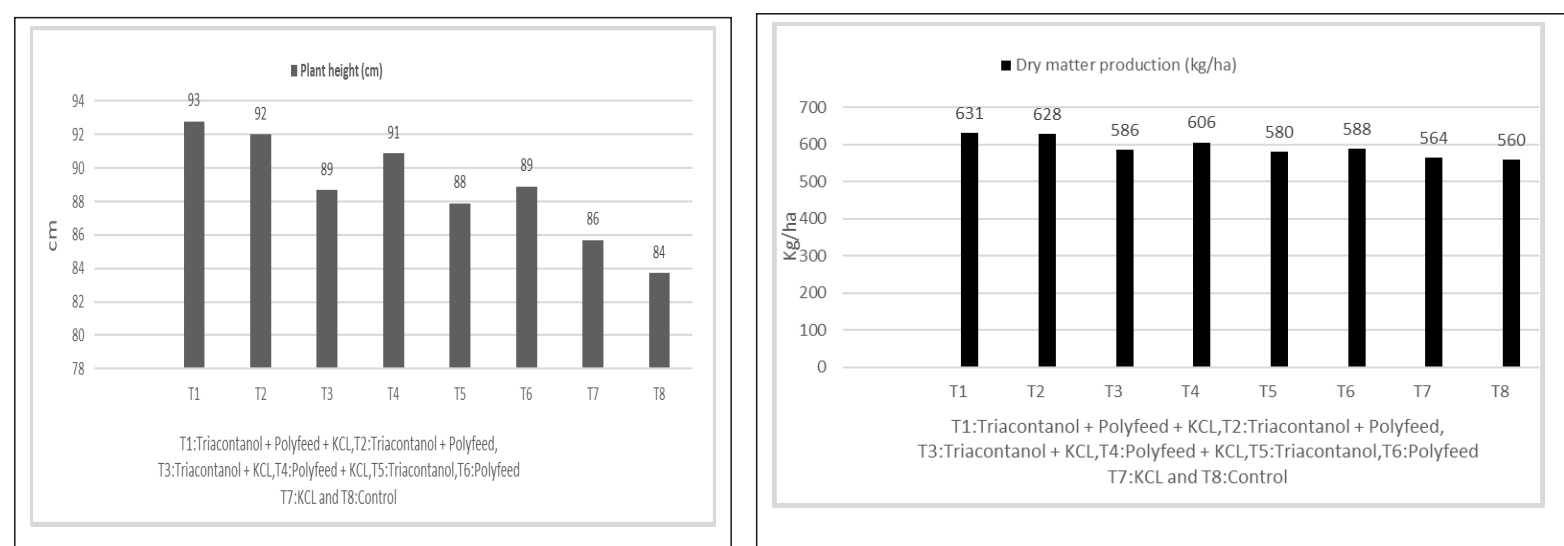

Figure 1. Effect of foliar spray of plant growth regulators and nutrients on plant height (cm) and Dry matter production (kg/ha) of rice

Foliar spray of Polyfeed increases the plant height by supplying more primary and micronutrients at tillering and flowering stages (Naik et al., 2002). Similar findings were reported by Pandey et al. (2001). The increase in total chlorophyll content due to foliar spray of $\mathrm{KNO}_{3}$ or urea was reported by Sritharan et al. (2005) in mung bean.

\section{Effect of foliar spray on yield}

Foliar application of plant growth regulators and nutrients combinations significantly influenced the yield and yield parameter (Figure 2). Triacontanol $2 \mathrm{ppm}+$ Polyfeed $1 \%+\mathrm{KCl} 1 \%$ spray at different stages increased the productive tillers $\left(540 / \mathrm{m}^{2}\right)$ and lowered the sterility percentage (13.4\%) of rice.

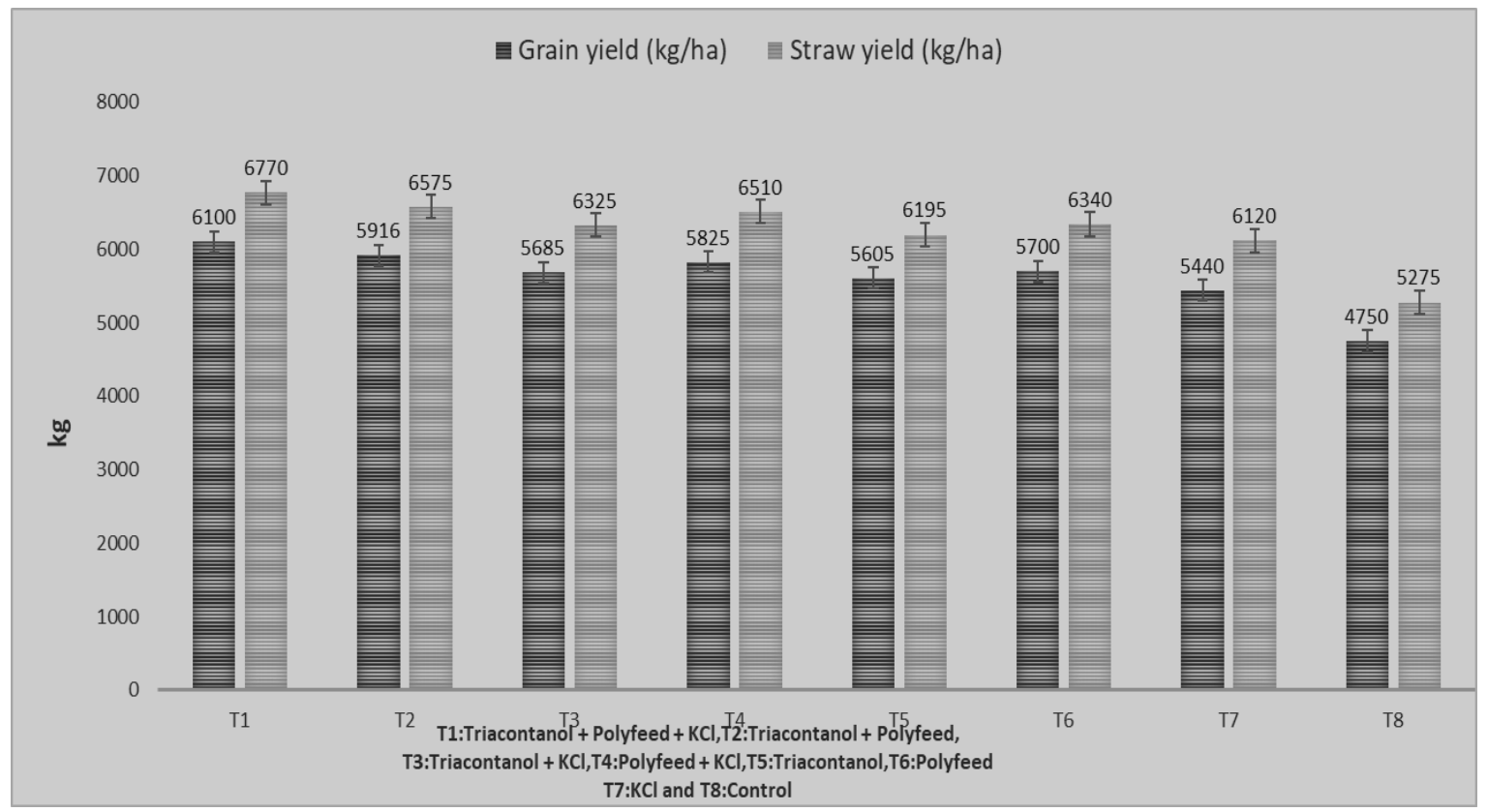

Figure 2. Effect of foliar spray of plant growth regulators and nutrients on yield ( $\left.\mathrm{kg} \mathrm{ha}^{-1}\right)$ of rice

This may be due to the effect of Triacontanol in reducing panicle senescence in rice by maintaining succinic dehydrogenase, thereby increasing the number of panicles per plant, panicle weight, and grain yield (Sharma et al. 2006). Foliar spraying of PGR and nutrients effectively absorbed by the plant and translocated more efficiently to the developing panicles, aiding in the proper filling of the grain. This 
statement was also supported by Abdi et al. (2002). The polyfeed fertilizer provides nutrients (NPK) to the plant (Kharub et al., 2002) and $\mathrm{KCl}$ spray, increasing enzyme activity, improving the synthesis of protein, carbohydrates and fats, translocation of photosynthates (Mengel and Kirkby, 1997). The enhancement of yield components through input management should pave the way for the maximization of rice grain yield. Foliar application of Triacontanol 2 ppm + Polyfeed 1\% $+\mathrm{KCl} 1 \%$ recorded the highest grain yield $\left(6100 \mathrm{~kg} \mathrm{ha}^{-1}\right)$ as well as straw yield (6770 kg ha-1). Plant growth regulators of triacontanol application in plants show higher photosynthetic efficiency and enhanced source to sink relationship of the plant, increased uptake of nutrients and water, enhanced translocation, and accumulation of sugar and other metabolites. This might be the reason for the increase in the grain and straw yield of rice (Aikins et al., 2010).

\section{CONCLUSION}

Plant growth regulators of triacontanol application in plants show higher photosynthetic efficiency and enhanced source to sink relationship of the plant, increased uptake of nutrients and water, enhanced translocation, and accumulation of sugar and other metabolites. This might be the reason for an increase in the grain and straw yield of Rice. It can be concluded that application of a recommended dose of fertilizers @ 150:50:50 kg NPK ha-1 and foliar spray of Triacontanol 2 ppm + Polyfeed $1 \%+$ $\mathrm{KCl} 1 \%$ given at 35 and 65 DAT is the viable nutrient management package to rabi rice for getting higher income through higher yield.

\section{REFERENCES}

Aikins, S.H.M., A. Bart-Plange and S. Opoku-Baffour. 2010. Performance evaluation of jab planters for maize planting and inorganic fertilizer application. J. Agric. and Bio. Sci., 5: 1-5.

Gomez, K.A. and Gomez, A.A. 1984. Statistical procedures for agricultural research. $2^{\text {nd }}$ edn. John Wiley and Sons. New York.p. 680.

GOTN. (Government of Tamil Nadu) 2015. Season and Crop report. Department of Economics and Statistics, Tamil Nadu.

Kharub, A.S., D.S. Chauhan, R.K. Sharma, S.C. Tripathi, R.S. Chhokar and V.K.Sharma. 2002.

Water soluble liquid fertilizers in wheat productivity and quality. Agric. Sci.Digest, 22(3): 161-163.

Mengel, K. and E.A. Kirkby. 1987. Principles of Plant Nutrition. $4^{\text {th }}$ ed., International Potash Institute, Basel, Switzerland.

Naik. L. B., Prabhakar, M. and Tiwari, R. B. 2002. Influence of foliar sprays with water-soluble fertilizers on yield and quality of Carrot (Daucus carota L). Proceedings in International Conference on Vegetables, Bangalore, p.183.

Pandey, A.K., Tripathi, R.S. and Yadav, R.S. 2001. Effect of certain growth regulators on growth, yield and quality of rice (Oryza sativa L.). Indian J. Agric. Res., 35(2): 118-120.

Sritharan, N., Aravazhi, A. and M.Vanangamudi. 2005. Effect of foliar spray of nutrients and plant growth regulators (PGRs) for yield maximization in blackgram. Madras Agric. J., 92(4-6): 301-307.

Sharma, N., S.R. Abrams and D.R. Waterer. 2006. Uptake, movement, activity, and persistence of an abscisic acid analog in marigold and tomato. J. Plant Growth Regu., 24: 28-35. 